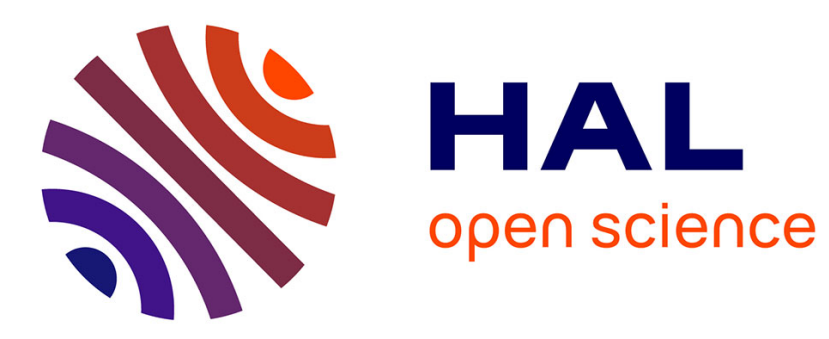

\title{
Novel and common BRCA1 mutations in familial breast/ovarian cancer patients from Lithuania
}

Ramūnas Janavičius, Ingrida Pepalytè, Vaidutis Kučinskas

\section{To cite this version:}

Ramūnas Janavičius, Ingrida Pepalytè, Vaidutis Kučinskas. Novel and common BRCA1 mutations in familial breast/ovarian cancer patients from Lithuania. Breast Cancer Research and Treatment, 2008, 117 (2), pp.467-469. 10.1007/s10549-008-0166-3 . hal-00486596

\section{HAL Id: hal-00486596 https://hal.science/hal-00486596}

Submitted on 26 May 2010

HAL is a multi-disciplinary open access archive for the deposit and dissemination of scientific research documents, whether they are published or not. The documents may come from teaching and research institutions in France or abroad, or from public or private research centers.
L'archive ouverte pluridisciplinaire HAL, est destinée au dépôt et à la diffusion de documents scientifiques de niveau recherche, publiés ou non, émanant des établissements d'enseignement et de recherche français ou étrangers, des laboratoires publics ou privés. 


\title{
Novel and common BRCA1 mutations in familial breast/ovarian cancer patients from Lithuania
}

\author{
Ramūnas Janavičius • Ingrida Pepalytė • \\ Vaidutis Kučinskas
}

Received: 18 August 2008/Accepted: 19 August 2008/Published online: 2 September 2008

(C) Springer Science+Business Media, LLC. 2008

\section{Background}

The germline mutations in the BRCA1 (MIM 113705) and BRCA2 (MIM600185) genes account for the majority of hereditary breast and ovarian cancers cases.

Founder mutations in BRCA1 gene have been recently described in Eastern Baltic Sea region, with variable distribution in Baltic (Latvian [1] and Lithuanian [2]) and Slavic (Polish [3], Belorussian [4], Russian [5]) populations, accounting for $80-90 \%$ of all mutations. However, data about its incidence in Lithuania are inconclusive and based on one study where only three mutations were tested in BRCA1 gene [2].

Here we present the complexity of BRCA1 gene mutation profile in familial breast and/or ovarian cancer index cases referred to Vilnius University Hospital Santariskiu Clinics from 1 year period (2006-2007).

\section{Methods}

During 1 year period (2006-2007) overall 28 unrelated index cases have attended cancer genetic clinic: 21 female

R. Janavičius $(\bowtie)$

Hematology, Oncology and Transfusion Medicine Center, Department of Molecular and Regenerative Medicine,

Vilnius University Hospital Santariskiu Clinics,

Santariskiu 2, Vilnius LT-08661, Lithuania

e-mail: ramunas.janavicius@ santa.lt

R. Janavičius · I. Pepalytė · V. Kučinskas

Department of Human and Medical Genetics, Vilnius University,

Santariskiu 2, Vilnius LT-08661, Lithuania

V. Kučinskas

Center for Medical Genetics, Vilnius University Hospital

Santariskiu Clinics, Santariskiu 2, Vilnius LT-08661, Lithuania patients diagnosed with breast cancer, 4 with ovarian cancer and 3 with both breast and ovarian cancer. Comprehensive genetic counselling was performed and after written informed consent genetic material for analysis was obtained from the youngest possible affected individual from each family.

Genomic DNA was extracted from peripheral blood leukocytes with standard ethanol-chlorophorm method. BRCA1 gene testing was initiated with direct sequencing using ABI Prism 3130XL Genetic Analyzer for already reported common founder mutations: c.4035delA in 11 exon, c.5266dupC in 20 exon and with restriction enzyme digestion (Eco471, MSI Fermentas, Lithuania) for c. $181 \mathrm{~T}>\mathrm{G}$ in 5 exon.

After the exclusion of common mutations, gene dosage analysis by multiplex ligation-dependent probe amplification (MLPA P002 kit, MRC Holland) and prescreening by denaturing gradient gel electrophoresis (BRCA1 Ingeny Kit) combined with direct sequencing were performed.

\section{Results}

Pathogenic BRCA1 gene mutations were found in 9 of the 28 (32\%) unrelated proband patients. Two mutationsc.5266dupC and c.4035delA-accounted for 44 and $33 \%$ for all identified mutations respectively. Novel protein truncating mutation c.4516delG was found in breast and ovarian cancer patient. Pathogenic nonsense substitution c. $1687 \mathrm{C}>\mathrm{T}$ was also detected in breast cancer patient (Table 1). Mutations were present in 19, 50 and $100 \%$ of breast, ovarian and both breast and ovarian cancer cases, respectively. No c.181T $>\mathrm{G}$ mutation and BRCA1 rearrangements were found. 


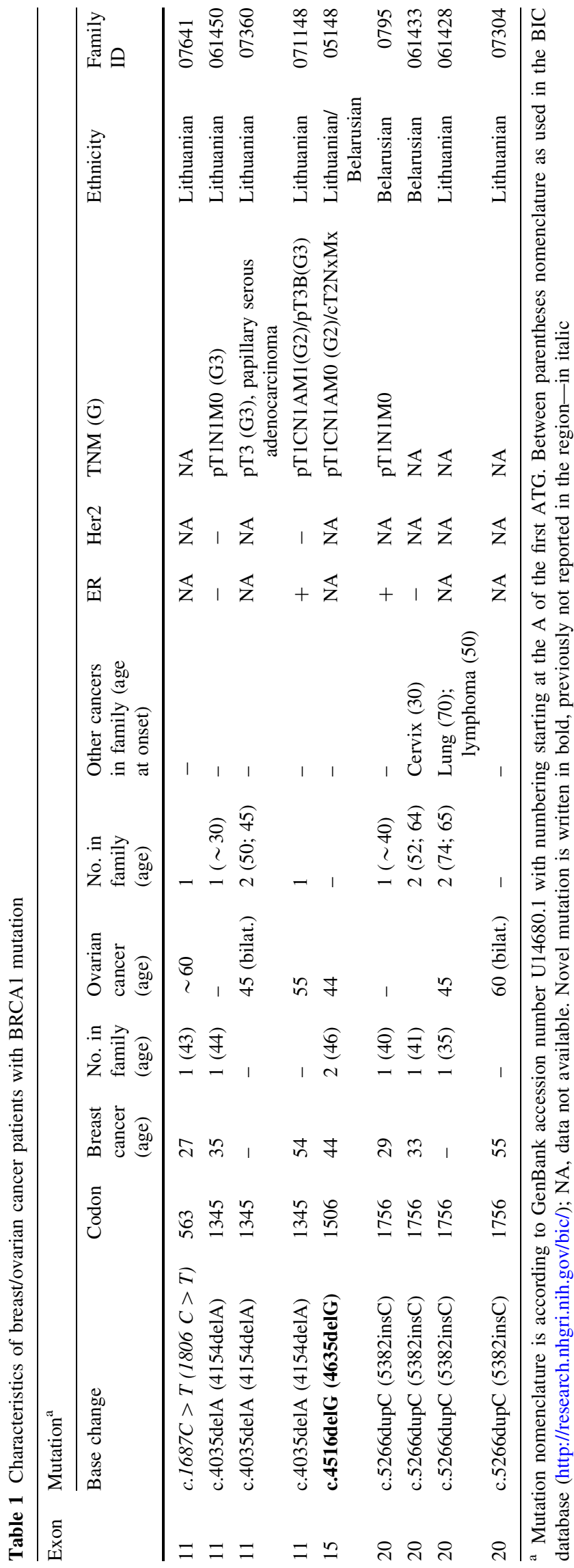

Polymorphic variants in BRCA1 gene were found: 2201C/T, 2430T/C, 2731C/T, 3232A/G, 3667A/G, 4427T/C and $4956 \mathrm{~A} / \mathrm{G}$.

\section{Discussion}

The results from our hospital-based analysis bring several important findings. Firstly, they show complexity of BRCA1 gene mutation pattern in Lithuania. We found pathogenic deletion in exon 15 not described elsewhere in the world and nonsense substitution previously was not reported in Eastern Baltic Sea region or neighboring populations. We did not yet found large rearrangements, but they are not so uncommon [6]. Secondly, mutations in BRCA1 gene are influenced by significant founder effect which is similar to that reported from Latvian (Baltic) population [1] and in our study were attributed to $78 \%$ of detected mutations. Interestingly, c.4035delA mutation was more frequent in families of Baltic origin (Lithuanians) (3/6), thus supporting Baltic Sea region origin hypothesis of this mutation [1,2], compared with Slavic (Belarusians) ethnicity, where Slavic/Ashkenazi c.5266dupC mutation was the most prevalent (2/3). This knowledge can be important in clinical decision making for subjecting patients to mutation testing. Thirdly, BRCA1 mutation detection rate for index patients diagnosed with breast cancer $\leq 35$ year was $33 \%$ (4/12) and mutations were absent in breast cancer patients group diagnosed after 36 years $(0 / 6)$. Therefore we propose that genetic testing, at least for two common c.5266dupC and c.4035delA mutations in BRCA1 gene, should be strongly considered in all female cancer cases diagnosed with breast cancer under 35 year; breast and ovarian cancer regardless the age; invasive, nonmucinous epithelial ovarian tumor regardless the age.

After the exclusion of common mutations, full BRCA1 gene analysis is further warranted in cases with a significant family history or synchronous/metachronous primary cancers.

This suggested hierarchical, cost-effective BRCA1 mutation screening protocol may have impact on the clinical management of breast-ovarian cancer families on a national healthcare system level.

\section{References}

1. Tikhomirova L, Sinicka O, Smite D, Eglitis J, Hodgson SV, Stengrevics A (2005) High prevalence of two BRCA1 mutations, 4154delA and 5382insC, in Latvia. Fam Cancer 4(2):77-84. doi: 10.1007/s10689-004-2758-3 
2. Gronwald J, Elsakov P, Górski B, Lubiński J (2005) High incidence of 4153delA BRCA1 gene mutations in Lithuanian breast- and breast-ovarian cancer families. Breast Cancer Res Treat 94(2):111-113. doi:10.1007/s10549-005-5150-6

3. Górski B, Byrski T, Huzarski T, Jakubowska A, Menkiszak J, Gronwald J et al (2000) Founder mutations in the BRCA1 gene in Polish families with breast-ovarian cancer. Am J Hum Genet 66(6):1963-1968. doi:10.1086/302922

4. Oszurek O, Gorski B, Gronwald J, Prosolow Z, Uglanica K, Murinow A et al (2001) Founder mutations in the BRCA1 gene in west Belarusian breast-ovarian cancer families. Clin Genet 60(6):470-471. doi:10.1034/j.1399-0004.2001.600611.x

5. Sokolenko AP, Mitiushkina NV, Buslov KG, Bit-Sava EM, Iyevleva AG, Chekmariova EV et al (2006) High frequency of BRCA1 5382insC mutation in Russian breast cancer patients. Eur J Cancer 42(10):1380-1384. doi:10.1016/j.ejca.2006.01.050

6. Ratajska M, Brozek I, Senkus-Konefka E, Jassem J, Stepnowska $\mathrm{M}$, Palomba $\mathrm{G}$ et al (2008) BRCA1 and BRCA2 point mutations and large rearrangements in breast and ovarian cancer families in Northern Poland. Oncol Rep 19(1):263-268 